\title{
Cut-Off Values of Hematologic Parameters to Predict the Number of Alpha Genes Deleted in Subjects with Deletional Alpha Thalassemia
}

\author{
Diego Velasco-Rodríguez ${ }^{1}{ }^{*}$, Carlos Blas ${ }^{1}$, Juan-Manuel Alonso-Domínguez ${ }^{1}$, Gala Vega ${ }^{1}$, \\ Carlos Soto ${ }^{1}$, Aránzazu García-Raso ${ }^{1}$ and Pilar Llamas-Sillero ${ }^{2}$ \\ 1 Servicio de Hematología, Hospital Universitario, Fundación Jiménez Díaz, IIS-FJD, \\ Universidad Autónoma de Madrid, 28029 Madrid, Spain; cblas@quironsalud.es (C.B.); \\ juan.adominguez@fjd.es (J.-M.A.-D.); gala.vega@quironsalud.es (G.V.); csoto@fjd.es (C.S.); \\ argarciar@quironsalud.es (A.G.-R.) \\ 2 Servicio de Hematología, Hospitales Quirón Públicos, IIS-FJD, Universidad Autónoma de Madrid, \\ 28029 Madrid, Spain; pllamas@fjd.es \\ * Correspondence: diegovelascorodriguez@gmail.com; Tel.:+34-915-504-800 (ext. 2683)
}

Received: 19 September 2017; Accepted: 9 December 2017; Published: 13 December 2017

\begin{abstract}
Most $\alpha$-thalassemia cases are caused by deletions of the structural $\alpha$-globin genes. The degree of microcytosis and hypochromia has been correlated with the number of affected $\alpha$-globin genes, suggesting a promising role of hematologic parameters as predictive diagnostic tools. However, cut-off points for these parameters to discriminate between the different subtypes of $\alpha$-thalassemia are yet to be clearly defined. Six hematologic parameters $(\mathrm{RBC}, \mathrm{Hb}, \mathrm{MCV}, \mathrm{MCH}, \mathrm{MCHC}$ and RDW) were evaluated in 129 cases of deletional $\alpha$-thalassemia (56 heterozygous $\alpha^{+}$thalassemia, 36 homozygous $\alpha^{+}$thalassemia, 29 heterozygous $\alpha^{0}$ thalassemia and 8 cases of $\mathrm{Hb} \mathrm{H}$ disease). A good correlation between the number of deleted alpha genes and MCV $(r=-0.672, p<0.001)$, $\mathrm{MCH}(r=-0.788, p<0.001)$ and RDW $(r=0.633, p<0.001)$ was observed. The presence of an $\alpha^{0}$ allele should be discarded in individuals with microcytosis without iron deficiency and normal values of $\mathrm{Hb} \mathrm{A}_{2}$ and $\mathrm{Hb} \mathrm{F}$ with $\mathrm{MCH}<23.40 \mathrm{pg}$. Furthermore, $\mathrm{MCH}<21.90 \mathrm{pg}$ and/or $\mathrm{MCV}<70.80 \mathrm{fL}$ are strongly suggestive of the presence of one $\alpha^{0}$ allele. Finally, an accurate presumptive diagnosis of $\mathrm{Hb}$ $\mathrm{H}$ disease can be made if both $\mathrm{RDW} \geq 20 \%$ and $\mathrm{MCH}<19 \mathrm{pg}$ are seen.
\end{abstract}

Keywords: alpha; thalassemia; deletional; cut-off; number of genes; microcytic anemia; differential diagnosis

\section{Introduction}

Alpha-thalassemia is the most prevalent isolated genetic disorder worldwide [1]. Its geographic distribution is highly variable, and the highest prevalence is seen in several regions of China and Southeast Asia [2-7], and also in the Mediterranean and Middle Eastern regions [8]. However, migration flows in the last decades have significantly increased its prevalence in the rest of the world and, consequently, the amount of people needing diagnosis and management of this condition is increasing, especially in developed countries $[5,8,9]$.

The $\alpha$-globin gene cluster is located at the short arm of chromosome 16 (16p13.3) and contains 2 functional $\alpha$ genes, a $\zeta$ gene, 3 pseudogenes $(\Psi \alpha 1, \Psi \alpha 2, \Psi \zeta 1)$ and a $\theta 1$ gene of undetermined function $[10,11]$. Normal subjects have $4 \alpha$ genes $(\alpha \alpha / \alpha \alpha), 2$ on each chromosome.

The majority of $\alpha$-thalassemia cases are caused by deletions of the structural $\alpha$-globin genes, whereas single point mutations or nucleotide insertions (nondeletional $\alpha$-thalassemia) are much less frequent [1]. 
There are four types of deletional $\alpha$-thalassemia, and their severity is correlated with the number of affected $\alpha$-globin genes [1,11-14]. Carriers of only one $\alpha$ gene deletion $\left(\alpha^{+}\right.$thalassemia) have slightly decreased values of mean corpuscular volume (MCV) and mean corpuscular hemoglobin $(\mathrm{MCH})$, being sometimes overlapped with normal values [1,10-12]. Both homozygosis for $\alpha^{+}$thalassemia $(-\alpha /-\alpha)$ and the heterozygous form of $\alpha^{0}$ thalassemia $(-/ \alpha \alpha)$ cause mild microcytic and hypochromic anemia [1,10-12]. These milder forms of $\alpha$-thalassemia can ameliorate the severity of $\beta$-thalassemia major and sickle cell disease when they are co-inherited [15-17].

Individuals with the loss of three $\alpha$ genes [Hemoglobin $(\mathrm{Hb}) \mathrm{H}$ disease], characteristically have microcytic hypochromic chronic hemolytic anemia with acute episodes of hemolysis in response to oxidant drugs and infections, splenomegaly and mild jaundice $[6,10,12,18]$. When the four $\alpha$-globin genes are deleted ( $\mathrm{Hb}$ Bart hydrops fetalis syndrome), fetal onset of generalized edema, severe hypochromic anemia, marked hepatosplenomegaly, extramedullary erythropoiesis, and death in the neonatal period are developed $[6,12,18]$.

Since $\alpha$-thalassemia carriers show normal levels of $\mathrm{Hb} \mathrm{A}_{2}$ and $\mathrm{Hb}$, molecular analysis of the $\alpha$-globin cluster is required for the diagnosis [1]. The polymerase chain reaction (PCR) is the most common method to diagnose deletional $\alpha$-thalassemia, although other techniques such as Multiplex Ligation dependent Probe Amplification (MLPA) are widely used [19].

Differences in laboratory parameters of red blood cells (RBC) between subtypes of deletional $\alpha$-thalassemia have been evaluated, and a promising role as predictive diagnostic tools has been suggested $[13,14,20]$. However, no cut-off points for those parameters have been defined so far.

The aims of this work were to describe the phenotype of RBC based on laboratory parameters of individuals with any form of deletional $\alpha$-thalassemia, and to evaluate whether the number of deleted alpha genes can be predicted by precise cut-off points of the hematologic parameters.

\section{Results}

The reliability of the results of the complete blood count, $\mathrm{Hb} \mathrm{A}_{2}$ and $\mathrm{Hb} \mathrm{F}$ is guaranteed with daily internal quality control (provided by the manufacturer) and external quality assessment every month (Hemqual program, Sociedad Española Hematología y Hemoterapia). Internal quality controls are performed to guarantee that results of the molecular analysis are also reliable.

Of the 129 cases finally included in the study, 57 (44.19\%) were males and 72 (55.81\%) females and the median age was 35.50 years (3-81).

According to the number of deleted alpha genes, each individual was allocated to one of the following groups:

1. Loss of one $\alpha$ gene or heterozygous $\alpha^{+}$thalassemia $(-\alpha / \alpha \alpha)(n=56)(43.42 \%)$. The $\alpha^{3.7}$ haplotype was observed in 55 cases ( 19 men, 21 women and 15 children), whereas the $\alpha^{4.2}$ haplotype was found only in 1 woman.

2. Loss of two $\alpha$ genes from different chromosomes $(-\alpha /-\alpha)(n=36)(27.90 \%)$ : 34 subjects with $-\alpha^{3.7} /-\alpha^{3.7}$ deletions (11 men, 19 women and 4 children), 1 man with $-\alpha^{4.2} /-\alpha^{4.2}$ deletions and 1 man was compound heterozygote for the $-\alpha^{3.7} /-\alpha^{4.2}$ mutations.

3. Loss of two $\alpha$ genes from the same chromosome or heterozygous $\alpha^{0}$ thalassemia $(-/ \alpha \alpha)(n=29)$ (22.48\%): This group was comprised of 16 _ SEA / $\alpha \alpha$ individuals ( 4 men, 8 women and 4 children) and 13 _ FIL $/ \alpha \alpha$ ( 2 men, 9 women and 2 children). Neither _-MED $/ \alpha \alpha$ nor $-\alpha^{20.5}$ individuals were identified. The nationalities of our $\left(\right.$ CEA $\left._{\mathrm{S}} / \alpha \alpha\right)$ cases were: 11 Filipino and 5 Chinese. All of $(\ldots$ FIL $/ \alpha \alpha)$ cases from our study were Filipino except one Spanish girl whose mother was Filipino.

4. Loss of three $\alpha$ genes or $\mathrm{Hb} \mathrm{H}$ disease $(-/-\alpha)(n=8)(6.20 \%): 4$ subjects presented the _ ${ }^{\mathrm{SEA}} /-\alpha^{3.7}$ genotype whereas the _- ${ }^{\mathrm{FIL}} /-\alpha^{3.7}$ genotype was found in 4 cases. All of them were born in the Philippines, except one Spanish girl whose grandfather was Filipino.

Hematological parameters of the 4 groups are summarized in Table 1. 
$\mathrm{No} \mathrm{Hb}$ Bart hydrops fetalis syndrome was diagnosed in the mentioned period of time.

None of the 40 subjects with normal hematological parameters carried any of the evaluated deletions.

Table 1. Hematologic parameters of the different subtypes of deletional $\alpha$-thalassemia. Data represent mean $\pm \mathrm{SD}$ (standard deviation).

\begin{tabular}{|c|c|c|c|c|c|}
\hline Parameter & Gender and Age & $\begin{array}{c}-\alpha / \alpha \alpha \\
n=56\end{array}$ & $\begin{array}{l}-\alpha /-\alpha \\
n=36\end{array}$ & $\begin{array}{l}-/ \alpha \alpha \\
n=29\end{array}$ & $\begin{array}{l}--\alpha \\
n=8\end{array}$ \\
\hline \multirow{3}{*}{$\mathrm{RBC}\left(\times 10^{12} / \mathrm{L}\right)$} & Male & $6.0 \pm 0.42$ & $5.9 \pm 0.64$ & $6.6 \pm 0.35$ & 6 \\
\hline & Female & $5.1 \pm 0.49$ & $5.4 \pm 0.59$ & $5.6 \pm 0.46$ & $5.8 \pm 0.43$ \\
\hline & Children 3-16 years & $5.4 \pm 0.33$ & $5.8 \pm 0.14$ & $6.1 \pm 0.51$ & $6.2 \pm 1.41$ \\
\hline \multirow{3}{*}{$\mathrm{Hb}(\mathrm{g} / \mathrm{dL})$} & Male & $15.3 \pm 0.94$ & $14.1 \pm 1.07$ & $14.3 \pm 1.03$ & 9.6 \\
\hline & Female & $12.9 \pm 0.98$ & $12.3 \pm 0.94$ & $11.8 \pm 0.73$ & $9.4 \pm 0.61$ \\
\hline & Children 3-16 years & $13.0 \pm 0.92$ & $11.5 \pm 0.59$ & $12.3 \pm 1.12$ & $9.6 \pm 0.56$ \\
\hline \multirow{3}{*}{$\mathrm{MCV}(\mathrm{fL})$} & Male & $79.4 \pm 2.75$ & $74.5 \pm 3.33$ & $68.1 \pm 2.00$ & 66.3 \\
\hline & Female & $78.3 \pm 3.60$ & $73.2 \pm 3.32$ & $68.6 \pm 3.52$ & $64.6 \pm 5.90$ \\
\hline & Children 3-16 years & $75.6 \pm 3.82$ & $64.4 \pm 3.58$ & $64.0 \pm 3.87$ & $61.1 \pm 9.33$ \\
\hline \multirow{3}{*}{$\mathrm{MCH}(\mathrm{pg})$} & Male & $25.8 \pm 1.68$ & $23.1 \pm 1.09$ & $21.5 \pm 1.58$ & 16 \\
\hline & Female & $25.1 \pm 1.74$ & $22.9 \pm 1.13$ & $21.0 \pm 0.99$ & $17.2 \pm 1.18$ \\
\hline & Children 3-16 years & $24.2 \pm 1.07$ & $20.4 \pm 0.86$ & $20.1 \pm 0.68$ & $15.8 \pm 2.61$ \\
\hline \multirow{3}{*}{$\mathrm{MCHC}(\mathrm{g} / \mathrm{L})$} & Male & $32.3 \pm 1.60$ & $31.0 \pm 0.98$ & $32.2 \pm 2.46$ & 24.2 \\
\hline & Female & $32.4 \pm 1.45$ & $31.2 \pm 1.16$ & $30.7 \pm 1.19$ & $25.9 \pm 0.95$ \\
\hline & Children 3-16 years & $31.7 \pm 1.38$ & $31.2 \pm 0.73$ & $31.5 \pm 1.00$ & $25.9 \pm 0.35$ \\
\hline \multirow{3}{*}{ RDW (\%) } & Male & $13.5 \pm 0.80$ & $14.97 \pm 1.45$ & $15.08 \pm 1.54$ & 23.3 \\
\hline & Female & $13.95 \pm 1.28$ & $14.60 \pm 1.01$ & $15.81 \pm 2.14$ & $21.6 \pm 1.40$ \\
\hline & Children 3-16 years & $14.15 \pm 0.96$ & $14.76 \pm 0.50$ & $14.61 \pm 0.79$ & $21.65 \pm 0.92$ \\
\hline
\end{tabular}

All the hematological parameters showed statistically significant differences $(p<0.05)$ between $\alpha^{+}$-thalassemia carriers $(-\alpha / \alpha \alpha)$ and normal controls $(\alpha \alpha / \alpha \alpha)$ (Table 2$)$. The $(-\alpha / \alpha \alpha)$ group presented significantly higher RBC count, lower $\mathrm{Hb}$, lower MCV, lower MCH lower MCHC and higher RDW. $\mathrm{MCV}, \mathrm{MCH}$ and $\mathrm{MCHC}$ stood out as the most efficient parameters to discriminate between these two groups. MCV showed an AUC of 0.975 and the cut-off point of 82.05 provided a sensitivity of $94.7 \%$ and a specificity of $94.9 \%$. MCH showed an AUC of 0.982 and the cut-off point of 27.35 provided a sensitivity of $94.70 \%$ and a specificity of $92.30 \%$. MCHC showed an AUC of 0.832 and the cut-off point of 33.35 provided a sensitivity of $77.20 \%$ and a specificity of $71.80 \%$.

Table 2. Comparison of hematologic parameters of heterozygous $\alpha^{+}$thalassemia $(-\alpha / \alpha \alpha)$ and normal controls without $\alpha^{+}$thalassemia $(\alpha \alpha / \alpha \alpha)$. Data represent mean $\pm \operatorname{SD}$ (standard deviation). $p$ values less than 0.05 were considered statistically significant.

\begin{tabular}{cccc}
\hline Parameter & $\begin{array}{c}(\alpha \boldsymbol{\alpha} / \boldsymbol{\alpha \alpha}) \\
\boldsymbol{n}=\mathbf{4 0}\end{array}$ & $\begin{array}{c}(-\alpha / \alpha \boldsymbol{\alpha}) \\
\boldsymbol{n = 5 6}\end{array}$ & $\boldsymbol{p}$ Value \\
\hline $\mathrm{RBC}\left(\times 10^{12} / \mathrm{L}\right)$ & $5.20 \pm 0.46$ & $5.53 \pm 0.53$ & 0.003 \\
$\mathrm{Hb}(\mathrm{g} / \mathrm{dL})$ & $14.69 \pm 1.32$ & $12.7 \pm 1.33$ & 0.001 \\
$\mathrm{MCV}(\mathrm{fL})$ & $83.97 \pm 1.31$ & $77.33 \pm 3.75$ & $<0.001$ \\
$\mathrm{MCH}(\mathrm{pg})$ & $28.32 \pm 0.91$ & $24.83 \pm 1.68$ & $<0.001$ \\
$\mathrm{MCHC}(\mathrm{g} / \mathrm{dL})$ & $33.71 \pm 0.91$ & $32.11 \pm 1.47$ & $<0.001$ \\
$\mathrm{RDW}(\%)$ & $13.37 \pm 0.95$ & $14.07 \pm 1.07$ & 0.002 \\
\hline
\end{tabular}

Statistically significant differences $(p<0.05)$ were observed in all the hematological parameters between $\alpha^{+}$-thalassemia carriers and those subjects with 2 alpha genes deleted $((-\alpha /-\alpha)$ and $(--/ \alpha \alpha))$ (Table 3). Individuals with two alpha genes deleted presented significantly higher RBC count 
$\left(5.79 \times 10^{12} / \mathrm{L}\right.$ vs. $\left.5.53 \times 10^{12} / \mathrm{L}, p=0.016\right)$, lower $\mathrm{Hb}(12.63 \mathrm{~g} / \mathrm{dL}$ vs. $13.7 \mathrm{~g} / \mathrm{dL}, p<0.001)$, lower MCV (70.20 fL vs. $77.33 \mathrm{fL}, p<0.001)$, lower MCH (21.89 pg vs. $24.83 \mathrm{pg}, p<0.001)$, lower MCHC (31.21 g/dL vs. $32.11 \mathrm{~g} / \mathrm{dL}, p<0.001)$ and higher RDW (15.04\% vs. $14.07 \%, p<0.001)$. Only MCV and $\mathrm{MCH}$ demonstrated to be efficient enough to discriminate between these subgroups. MCV showed an AUC of 0.879 and a cut-off point of 74.05 provided a sensitivity of $85.70 \%$ and a specificity of $78.50 \%$. $\mathrm{MCH}$ showed an AUC of 0.905 and the cut-off point of 23.40 provided a sensitivity of $85.70 \%$ and a specificity of $78.50 \%$.

Table 3. Comparison of hematologic parameters in subjects with loss of 1 alpha gene and those with two genes affected. Data represent mean $\pm \mathrm{SD}$ (standard deviation). $p$ values less than 0.05 were considered statistically significant.

\begin{tabular}{cccc}
\hline Parameter & $\begin{array}{c}\text { Loss of 1 Gene } \\
(-\alpha / \alpha \boldsymbol{\alpha}) \\
\boldsymbol{n}=\mathbf{5 6}\end{array}$ & $\begin{array}{c}\text { Loss of 2 Genes } \\
(-\alpha /-\alpha),(-/ \alpha \boldsymbol{\alpha}) \\
\boldsymbol{n = 6 5}\end{array}$ & $\boldsymbol{p}$ Value \\
\hline $\mathrm{RBC}\left(\times 10^{12} / \mathrm{L}\right)$ & $5.53 \pm 0.53$ & $5.79 \pm 0.63$ & 0.019 \\
$\mathrm{Hb}(\mathrm{g} / \mathrm{dL})$ & $13.7 \pm 1.41$ & $12.63 \pm 1.35$ & $<0.001$ \\
$\mathrm{MCV}(\mathrm{fL})$ & $77.33 \pm 3.75$ & $70.20 \pm 4.96$ & $<0.001$ \\
$\mathrm{MCH}(\mathrm{pg})$ & $24.83 \pm 1.68$ & $21.89 \pm 1.52$ & $<0.001$ \\
$\mathrm{MCHC}(\mathrm{g} / \mathrm{dL})$ & $32.11 \pm 1.47$ & $31.21 \pm 1.30$ & 0.001 \\
$\mathrm{RDW}(\%)$ & $14.07 \pm 1.07$ & $15.04 \pm 1.52$ & $<0.001$ \\
\hline
\end{tabular}

Comparison of $(-\alpha /-\alpha)$ and $(-/ \alpha \alpha)$ revealed significantly lower MCV $(67.34 \mathrm{fL}$ vs. $72.51 \mathrm{fL}$, $p<0.001)$ and lower MCH (21.02 pg vs. $22.59 \mathrm{pg}, p<0.001)$ in $(-/ \alpha \alpha)$ subjects (Table 4$)$. No significant differences were found in RBC, Hb, MCHC and RDW. MCV showed an AUC of 0.815 and the cut-off point of 70.20 provided a sensitivity of $82.80 \%$ and a specificity of $77.80 \%$. MCH showed an AUC of 0.810 and the cut-off point of 21.90 provided a sensitivity of $82.80 \%$ and a specificity of $64.90 \%$.

Table 4. Comparison of hematologic parameters of homozygous $\alpha^{+}$thalassemia $(-\alpha /-\alpha)$ and heterozygous $\alpha^{0}$ thalassemia (--/ $\left.\alpha \alpha\right)$. Data represent mean $\pm \operatorname{SD}$ (standard deviation). $p$ values less than 0.05 were considered statistically significant.

\begin{tabular}{cccc}
\hline Parameter & $\begin{array}{c}(-\alpha /-\alpha) \\
\boldsymbol{n}=\mathbf{3 6}\end{array}$ & $\begin{array}{c}(-/ \alpha \boldsymbol{\alpha}) \\
\boldsymbol{n = 2 9}\end{array}$ & $\boldsymbol{p}$ Value \\
\hline $\mathrm{RBC}\left(\times 10^{12} / \mathrm{L}\right)$ & $5.56 \pm 0.61$ & $5.95 \pm 0.61$ & 0.064 \\
$\mathrm{Hb}(\mathrm{g} / \mathrm{dL})$ & $12.7 \pm 1.33$ & $12.5 \pm 1.38$ & 0.420 \\
$\mathrm{MCV}(\mathrm{fL})$ & $72.51 \pm 4.56$ & $67.34 \pm 3.88$ & $<0.001$ \\
$\mathrm{MCH}(\mathrm{pg})$ & $22.59 \pm 1.44$ & $21.02 \pm 1.12$ & $<0.001$ \\
$\mathrm{MCHC}(\mathrm{g} / \mathrm{dL})$ & $31.17 \pm 1.07$ & $31.25 \pm 1.55$ & 0.794 \\
$\mathrm{RDW}(\%)$ & $14.74 \pm 1.04$ & $15.41 \pm 1.92$ & 0.079 \\
\hline
\end{tabular}

Comparison of $(-\alpha / \alpha \alpha)$ and $(-\alpha /-\alpha)$ vs. $(-/ \alpha \alpha)$ was also performed in order to identify parameters that could discriminate subjects at risk of having children with $\mathrm{Hb} \mathrm{H}$ disease or $\mathrm{Hb}$ Bart hydrops fetalis syndrome (Table 5$)$. The $(-/ \alpha \alpha)$ group presented significantly higher RBC count $\left(5.95 \times 10^{12} / \mathrm{L}\right.$ vs. $\left.5.58 \times 10^{12} / \mathrm{L}, p=0.004\right)$, lower $\mathrm{Hb}(12.47 \mathrm{~g} / \mathrm{dL}$ vs. $13.33 \mathrm{~g} / \mathrm{dL}, p=0.006)$, lower MCV (67.34 fL vs. $75.45 \mathrm{fL}, p<0.001)$, lower MCH (21.02 pg vs. $23.96 \mathrm{pg}, p<0.001)$ and higher RDW $(15.41 \%$ vs. $14.33 \%, p<0.001)$. An AUC $\geq 0.8$ was found only in MCV and MCH. MCV showed an AUC of 0.902 and the cut-off point of 70.80 provided a sensitivity of $85.90 \%$ and a specificity of $86.20 \%$. $\mathrm{MCH}$ showed an AUC of 0.898 and the cut-off point of 21.90 provided a sensitivity of $84.80 \%$ and a specificity of $82.80 \%$. 
Table 5. Comparison of hematologic parameters of subjects with and without an $\alpha^{0}$ allele. Data represent mean $\pm \mathrm{SD}$ (standard deviation). $\quad p$ values less than 0.05 were considered statistically significant.

\begin{tabular}{cccc}
\hline Parameter & $\begin{array}{c}(-\alpha / \alpha \boldsymbol{\alpha}),(-\alpha /-\alpha) \\
\boldsymbol{n = 9 2}\end{array}$ & $\begin{array}{c}(-/ \alpha \boldsymbol{\alpha}) \\
\boldsymbol{n = 2 9}\end{array}$ & $\boldsymbol{p}$ Value \\
\hline $\mathrm{RBC}\left(\times 10^{12} / \mathrm{L}\right)$ & $5.58 \pm 0.56$ & $5.95 \pm 0.62$ & 0.004 \\
$\mathrm{Hb}(\mathrm{g} / \mathrm{dL})$ & $13.33 \pm 1.45$ & $12.47 \pm 1.37$ & 0.006 \\
$\mathrm{MCV}(\mathrm{fL})$ & $75.45 \pm 4.70$ & $67.34 \pm 3.88$ & $<0.001$ \\
$\mathrm{MCH}(\mathrm{pg})$ & $23.96 \pm 1.93$ & $21.02 \pm 1.12$ & $<0.001$ \\
$\mathrm{MCHC}(\mathrm{g} / \mathrm{dL})$ & $31.74 \pm 1.40$ & $31.25 \pm 1.55$ & 0.115 \\
$\mathrm{RDW}(\%)$ & $14.33 \pm 1.11$ & $15.41 \pm 1.92$ & $<0.001$ \\
\hline
\end{tabular}

Comparisons of the hematological parameters of the two most frequent forms of $\alpha^{0}$ thalassemia in our sample are summarized in Table 6.

Table 6. Hematologic parameters of (_-SEA $/ \alpha \alpha)$ and (_- FIL $/ \alpha \alpha)$. Data represent mean \pm SD (standard deviation). $p$ values less than 0.05 were considered statistically significant.

\begin{tabular}{cccc}
\hline Parameter & $\begin{array}{c}(-\mathbf{S E A} / \boldsymbol{\alpha} \boldsymbol{\alpha}) \\
\boldsymbol{n}=\mathbf{1 6}\end{array}$ & $\begin{array}{c}(-\mathbf{F I L} / \boldsymbol{\alpha} \boldsymbol{\alpha}) \\
\boldsymbol{n} \mathbf{1 3}\end{array}$ & $\boldsymbol{p}$ Value \\
\hline $\mathrm{RBC}\left(\times 10^{12} / \mathrm{L}\right)$ & $5.96 \pm 0.58$ & $5.93 \pm 0.67$ & 0.918 \\
$\mathrm{Hb}(\mathrm{g} / \mathrm{dL})$ & $12.4 \pm 1.33$ & $12.5 \pm 1.39$ & 0.694 \\
$\mathrm{MCV}(\mathrm{fL})$ & $67.06 \pm 4.56$ & $67.64 \pm 3.14$ & 0.694 \\
$\mathrm{MCH}(\mathrm{pg})$ & $20.95 \pm 1.34$ & $21.09 \pm 0.88$ & 0.745 \\
$\mathrm{MCHC}(\mathrm{g} / \mathrm{dL})$ & $31.29 \pm 1.97$ & $31.21 \pm 0.99$ & 0.894 \\
$\mathrm{RDW}(\%)$ & $15.29 \pm 1.75$ & $15.81 \pm 2.01$ & 0.097 \\
\hline
\end{tabular}

The $\mathrm{Hb} \mathrm{H}$ disease $(--/-\alpha)$ group presented a significant degree of anemia $(9.47 \mathrm{~g} / \mathrm{dL})$, more microcytosis (63.72 fL) and hypochromia (16.16 pg), and a marked anisocytosis (22.61\%).

ANOVA test showed statistically significant differences $(p<0.001)$ in $\mathrm{Hb}, \mathrm{MCV}, \mathrm{MCH}, \mathrm{MCHC}$ and RDW when carriers of the deletion of 1,2 and 3 genes were analyzed together. Pearson coefficient showed good correlation between the number of deleted alpha genes and each of the following parameters: $\mathrm{MCV}(r=-0.672, p<0.001), \mathrm{MCH}(r=-0.788, p<0.001)$ and $\mathrm{RDW}(r=0.633, p<0.001)$.

\section{Discussion}

Identification of at-risk couples prior to pregnancy by hematologic parameters could prevent the most severe forms of $\alpha$-thalassemia, especially if they belong to a population at risk for $\alpha^{0}$ thalassemia $(-/ \alpha \alpha)$.

When compared to normal controls, $(-\alpha / \alpha \alpha)$ subjects showed mild microcytosis and hypochromia, and MCV (cut-off $82.05 \mathrm{fL}$ ) and MCH (cut-off $27.35 \mathrm{pg}$ ) proved to be excellent parameters to discriminate between these two subgroups. A known $(-\alpha / \alpha \alpha)$ subject by definition will transmit at least one HBA gene to his/her offspring, thus there is no risk of having children with Hb Bart's disease. However, the importance of identifying $(-\alpha / \alpha \alpha)$ individuals relies on warning them that, if their couple shows microcytosis, a molecular study of $\alpha$-thalassemia should be performed prior to having children. Our results in $(-\alpha / \alpha \alpha)$ subjects are in accordance with those published by many authors $[13,14,20]$.

Two parameters (MCH and MCV) stood out as the most efficient to predict the deletion of two alpha genes, being their optimal cut-off values $23.40 \mathrm{pg}$ and $74.05 \mathrm{fL}$ respectively. Despite the detection of two deleted alpha genes has no considerable clinical impact (only mild anemia), it allows an adequate genetic counseling to at-risk couples. Overlapping $\mathrm{Hb}, \mathrm{RBC}, \mathrm{MCHC}$ and RDW values were found in $(-\alpha /-\alpha)$ and $(-/ \alpha \alpha)$, but the $(-/ \alpha \alpha)$ group presented a significantly higher degree of 
microcytosis and hypochromia. Although both MCV and MCH showed an AUC $\geq 0.8$, their optimal cut-offs could not accurately discriminate between both conditions.

The main issue in subjects with suspected $\alpha$-thalassemia is the identification of individuals carrying an $\alpha^{0}$ allele $((-/ \alpha \alpha)$ or $(-/-\alpha))$, since they may have children with $\mathrm{Hb} \mathrm{H}$ disease or $\mathrm{Hb}$ Bart's disease if their couples have $\alpha^{+}$thalassemia or $\alpha^{0}$ thalassemia respectively. Presumptive diagnosis of $\mathrm{Hb} \mathrm{H}$ disease $(--/-\alpha)$ is easy to make, since these subjects are usually symptomatic and show a characteristic phenotype. However, identifying $(-/ \alpha \alpha)$ individuals remains a challenge in clinical practice. In our study, MCH had the best AUC $(0.905)$ to discriminate $(-/ \alpha \alpha)$ from $(-\alpha / \alpha \alpha)$ and $(-\alpha /-\alpha)$, followed by MCV (0.879). According to our results, the presence of one $\alpha^{0}$ allele should be suspected if the $\mathrm{MCH}<21.90 \mathrm{pg}$ and/or the $\mathrm{MCV}<70.80 \mathrm{fL}$.

Among $(-/ \alpha \alpha)$ cases, no significant differences were observed between the deletions __SEA and __FIL, and all of the corpuscular indices were almost identical in these two subgroups (Table 6).

As an example of the impact of immigration flows in the increased prevalence of $\alpha$-thalassemia in our country, all the subjects from our study who had at least one $\alpha^{0}$ allele were Southeast Asian or had ancestries from this geographic area. Although there have been described several forms of $\alpha^{0}$ thalassemia of local ethnicity (_- MA , _ CANT, __SPAN) in Spain [13], most of $\alpha^{0}$ thalassemia cases in our country are __ ${ }^{\mathrm{SEA}}$ or ___ FIL deletion described in Asian people. We found interesting the absence of individuals with the _- MED in our study, since it has been previously described in Spain [21,22].

As previously described by several authors $[6,12-14,18,20]$, we found a more severe degree of anemia in $\mathrm{Hb} \mathrm{H}$ disease cases, with $\mathrm{Hb}$ levels 9-10 g/dL. In addition to this, all our cases showed $\mathrm{MCH}$ $<19 \mathrm{pg}$. Our phenotypic data related to the size and chromia of their erythrocytes are in agreement with previous reports. Finally, a RDW higher than $20 \%$ was found in the 8 cases of $\mathrm{Hb} \mathrm{H}$ disease included in our study. There are no specific data of RDW values in the different types of deletional $\alpha$-thalassemia in the work of Villegas et al., although a marked increase in RDW of $(-/-\alpha)$ subjects in comparison to other subgroups is mentioned [13]. Akhavan-Niaki et al. did not evaluate RDW in $\alpha$-thalassemia subjects [14]. However, Ahmad et al. described a marked anisocytosis, with mean RDW values of $26.20 \pm 6.7 \%$ [20]. High RDW can be explained by the imbalance in the $\alpha / \beta$-globin chain ratio produced in the $\mathrm{Hb} \mathrm{H}$ disease that leads to ineffective erythropoiesis, since unstable free $\beta$-globin chain tetramers precipitate in erythroid precursors [12]. Additionally, their elevated reticulocyte count compared to other forms of $\alpha$-thalassemia $[13,20]$ can also increase the RDW, since reticulocytes are larger than RBC.

Three parameters are strongly affected by the number of alpha genes deleted: $\mathrm{MCV}, \mathrm{MCH}$ and RDW. The strongest correlation was observed in MCH $(r=-0.788)$, followed by MCV $(r=-0.672)$ and RDW $(r=0.633)$. The more alpha genes deleted, the lower values of MCH and MCV, whereas RDW showed an opposite trend. These three parameters had consistently shown statistically significant differences and high values of AUC in most of comparisons between subgroups throughout the statistical analysis, especially MCH. Moreover, the stability of $\mathrm{MCH}$ during storage of blood samples is higher compared to MCV $[23,24]$. Based on this consideration, many authors recommend using $\mathrm{MCH}$ instead of MCV to screen for thalassemia. Our results are consistent with this recommendation.

To our knowledge, this is the first study that defines cut-off points of several corpuscular indices to discriminate between the different subtypes of deletional $\alpha$-thalassemia, adding value to an initial diagnostic approach of these conditions.

There might be three possible drawbacks in our study. First of all, the number of cases analyzed is low. However, it has been enough to find significant differences between subgroups. Secondly, non-deletional $\alpha$-thalassemia cases were not included, although only a minority is due to point mutations. In addition, finally, not all of the deletional forms of $\alpha$-thalassemia were evaluated. However, the GAP-PCR used in this study detects the most frequent deletional $\alpha$-thalassemia determinants. Detection of inclusion bodies with supravital stains was not systematically performed. 


\section{Materials and Methods}

Over a 5-year period (April 2012-May 2017), all the deletional alpha-thalassemia cases diagnosed in the Fundación Jiménez Díaz University Hospital by molecular analysis were initially included in this retrospective and observational study $(n=174)$. Since hematological parameters can sometimes be normal in $\alpha^{+}$thalassemia carriers, 40 subjects with normal hematological parameters were also analyzed as negative controls to evaluate the presence of alpha thalassemia even in cases without microcytosis and hypochromia. All patients were de-identified and anonymized prior to analysis. None of the subjects included had received a blood transfusion in the previous 3 months. All samples were collected in K3-EDTA anticoagulant (Vacutainer ${ }^{\mathrm{TM}}$, Becton-Dickinson, NJ, USA), and a complete blood count $(\mathrm{CBC})$, an iron panel (serum iron, ferritin, transferrin, and transferrin saturation index (TSI)), high-performance liquid chromatography (HPLC) and molecular analysis were performed in all samples.

$\mathrm{Hb} \mathrm{A}_{2}$ levels were lower than 3.5\% and $\mathrm{Hb} \mathrm{F}$ levels were lower than $3.4 \%$ in all cases, ruling out heterozygous $\beta$-thalassemia and heterozygous $\delta \beta$-thalassemia. Carriers of $\alpha$-thalassemia and additional hemoglobinopathy were not included in the study. Subjects with ferritin levels $<20 \mathrm{ng} / \mathrm{mL}$ and TSI $<18 \%$ were considered to have iron deficiency, and were not included in the statistical analysis. Individuals aged $\leq 2$ years were excluded since it is well known that values of both $\mathrm{Hb}$ and MCV are lower in children than in adults [25-27].

There was a man with the _- ${ }^{\mathrm{FIL}} / \alpha^{\mathrm{X}}$ genotype, which means he carried, not only the __FIL deletion in one allele, but also a non-identified deletion in the other allele. In this case, inclusion bodies were identified with brilliant cresyl blue stain. However, since sequencing or further molecular studies could not be performed, the patient was excluded from the analysis.

All data were extracted from the local laboratory information system.

No signed consent was obtained from the patients since all the tests had been performed as part of their clinical work-up. The study followed the ethical principles of the Helsinki Declaration and was previously approved by the ethical committee of our institution (PIC 94/2017_FJD, Comite de Ética de la Investigación de la Fundación Jiménez Díaz, on 25 July 2017).

\subsection{Analytical Methods}

A GAP-PCR assay of the most frequent deletions that cause $\alpha$-thalassemia (_- ${ }^{\text {SEA }}$, _- FIL, _-MED $,-\alpha^{20.5},-\alpha^{3.7}$ and $-\alpha^{4.2}$ ) was carried out in all 174 patients as previously described [28], with minor modifications. Genomic DNA was extracted from leukocytes using QIAsymphony system (Qiagen GmbH, Hilden, Germany). Extracted genomic DNA was tested for its quality and quantity using Nanodrop 1000 Spectrophotometer (Thermo Fisher Scientific Inc., Wilmington, DE, USA).

The sequences of the PCR primers are listed in Table 7. Since each of the 6 deletions either partially or completely removes the $\alpha 2$ gene [28], its positive amplification was used to indicate heterozygosis when a deletion allele was also present. Each deletion was tested in a different reaction tube, including positive and negative $\left(\mathrm{H}_{2} \mathrm{O}\right.$ without DNA) controls. The combinations of primers to detect each deletion are summarized in Table 8 . Each $50 \mu \mathrm{L}$ reaction contained $1 \times$ PCR buffer containing Tris-Cl, $\mathrm{KCl},\left(\mathrm{NH}_{4}\right)_{2} \mathrm{SO}_{4}, \mathrm{pH} 8.7 ; 1.5 \mathrm{mmol} / \mathrm{L} \mathrm{MgCl}_{2}, 1 \mathrm{~mol} / \mathrm{L}$ betaine (SIGMA, St. Louis, MO, USA), $25 \mathrm{pmol}$ of each primer, $0.2 \mathrm{mmol} / \mathrm{L}$ of each dNTP, $2 \mathrm{U}$ of HotStar Taq DNA polymerase (Qiagen GmbH, Hilden, Germany) and 250 ng of genomic DNA. Reactions were carried out on a thermal cycler (SimpliAmp ${ }^{\mathrm{TM}}$ Thermal Cycler, Thermo Fisher, Singapore), with an initial 15 -min denaturation at $95^{\circ} \mathrm{C}$, 35 cycles of $95{ }^{\circ} \mathrm{C}$ for $45 \mathrm{~s}, 60^{\circ} \mathrm{C}$ for $1 \mathrm{~min}, 72{ }^{\circ} \mathrm{C}$ for $2 \mathrm{~min} 30 \mathrm{~s}$, and a final extension at $72{ }^{\circ} \mathrm{C}$ for $5 \mathrm{~min}$. Following amplification, $10 \mu \mathrm{L}$ of product was electrophoresed through a $1 \%$ agarose, $1 \times$ TBE gel at $80 \mathrm{~V}$ for $1 \mathrm{~h}$, stained in ethidium bromide, and visualized on an ultraviolet transilluminator. 
Table 7. Primers for PCR analysis of common $\alpha$-thalassemia deletions.

\begin{tabular}{ccc}
\hline Name & \multicolumn{1}{c}{ Sequence $\mathbf{( 5}^{\prime} \mathbf{- 3}^{\prime} \mathbf{)}$} & $\begin{array}{c}\text { Nucleotides } \\
\text { (GenBank ID NT_010393) }\end{array}$ \\
\hline FIL-F & TGCAAATATGTTTCTCTCATTCTGTG & $140821-140846$ \\
FIL-R & ATAACCTTTATCTGCCACATGTAGC & $172662-172638$ \\
$20.5-F$ & GCCCAACATCCGGAGTACATG & $147041-147061$ \\
$3.7 / 20.5-\mathrm{R}$ & AAAGCACTCTAGGGTCCAGCG & $167719-167699$ \\
MED-F & TACCCTTTGCAAGCACACGTAC & $152260-152281$ \\
MED-R & TCAATCTCCGACAGCTCCGAC & $170340-170320$ \\
SEA-F & CGATCTGGGCTCTGTGTTCTC & $155257-155277$ \\
SEA-R & AGCCCACGTTGTGTTCATGGC & $175909-175889$ \\
$4.2-F$ & GGTTTACCCATGTGGTGCCTC & $159269-159288$ \\
$4.2-R$ & CCCGTTGGATCTTCTCATTTCCC & $165142-165120$ \\
$\alpha 2 / 3.7-F$ & CCCCTCGCCAAGTCCACCC & $161883-161901$ \\
$\alpha 2-R$ & AGACCAGGAAGGGCCGGTG & $163685-163667$ \\
\hline
\end{tabular}

Table 8. Combinations of primers to detect each deletion.

\begin{tabular}{ccc}
\hline Fragment & Primers & Size (bp) \\
\hline FIL deletion & FIL-F + FIL-R & 1166 \\
SEA deletion & SEA-F + SEA-R & 1349 \\
20.5 deletion & $20.5 \mathrm{~F}+3.7 / 20.5-\mathrm{R}$ & 1007 \\
3.7 deletion & $\alpha 2-3.7-\mathrm{F}+3.7 / 20.5-\mathrm{R}$ & $2022-2029$ \\
4.2 deletion & $4.2 \mathrm{~F}+4.2-\mathrm{R}$ & 1628 \\
MED deletion & MED-F + MED-R & 807 \\
$\alpha 2$ gene & $\alpha 2 / 3.7-\mathrm{F}+\alpha 2-\mathrm{R}$ & 1800 \\
\hline
\end{tabular}

The CBC was performed with the Advia 2120 analyzer (Siemens Medical Solutions Diagnostics, Tarrytown, NY, USA). The following parameters of the CBC were assessed in all subjects: absolute RBC count, $\mathrm{Hb}, \mathrm{MCV}, \mathrm{MCH}$, mean corpuscular hemoglobin concentration (MCHC) and RBC distribution width (RDW). Ferritin, transferrin, and TSI were measured by chemiluminescence immunoassay in the Advia Centaur (Siemens Medical Solutions Diagnostics). $\mathrm{Hb} \mathrm{\textrm {A } _ { 2 }}$ and $\mathrm{Hb} \mathrm{F}$ levels were determined by HPLC on the Tosoh G7 analyzer (Horiba, Tokyo, Japan).

\subsection{Statistical Analysis}

The sample was divided into 3 different groups according to gender and age for the statistical analysis: (1) male and female children from 3 to 16 years; (2) females $\geq 16$ years; (3) males $\geq 16$ years. Cases were also classified according to the number of deleted alpha genes: 1, 2 or 3 .

All measurements were expressed as the median \pm standard deviation (SD). The Shapiro-Wilk test was used to assess the normality of our dataset in case of less than 30 samples per group in the comparation. An independent sample t-test was used to compare classical hematologic parameters among the different subgroups. In case of less than 30 samples per group and non-normal distribution, non-parametric tests were used (Mann-Whitney). Additionally, non-parametric tests were used when any of the subgroups compared had less than 30 members. $p$ values less than 0.05 were considered statistically significant. Receiver operating characteristic (ROC) curves were plotted in all the parameters that showed significant differences and their area under the curve (AUC) used to evaluate their diagnostic performance. An arbitrary value of AUC $\geq 0.8$ was used as the cut-off for considering a variable to be efficient enough to discriminate between the different subgroups. For those variables, a cut-off was selected based on its sensitivity and specificity.

One-way ANOVA test was used to compare the median values of each parameter in three groups of subjects according to the number of deleted alpha genes. Kruskal-Wallis test was performed in the case of parameters of samples whose variances were not equal and groups were very different in size. 
The Pearson coefficient was estimated to assess the correlation between each of the hematological parameters and the number of alpha genes deleted. An arbitrary value of $r \geq 0.6$ was considered a good correlation.

SPSS version 19.0 for Windows (SPSS, Chicago, IL, USA) was used for statistical analysis of the data.

\section{Conclusions}

Unequivocal diagnosis of $\alpha$-thalassemia can only be made with molecular studies, but corpuscular indices provided by hematological counters can be of great utility as predictive markers of the number of alpha genes deleted. According to our results it is mandatory to discard the deletion of at least two alpha genes in individuals with microcytosis without iron deficiency and normal values of $\mathrm{Hb} \mathrm{\textrm {A } _ { 2 }}$ and $\mathrm{Hb} \mathrm{F}$ when $\mathrm{MCH}$ levels are lower than $23.40 \mathrm{pg}$. Additionally, the presence of one $\alpha^{0}$ allele should be suspected with $\mathrm{MCH}<21.90 \mathrm{pg}$ and/or MCV $<70.80 \mathrm{fL}$. In this setting, $\mathrm{Hb} \mathrm{H}$ disease will be the most likely diagnosis if $\mathrm{RDW} \geq 20 \%$ and/or $\mathrm{MCH}<19 \mathrm{pg}$ are seen. Further prospective validation of these cut-off points in cohorts with larger sample size is needed to establish their real utility in daily clinical practice.

Acknowledgments: We are grateful to Fernando Ataúlfo González for his valuable comments and support.

Author Contributions: Diego Velasco-Rodríguez, Juan-Manuel Alonso-Domínguez and Carlos Blas conceived and designed the study; Carlos Blas performed the molecular analysis; Carlos Soto validated the hematologic parameters; Diego Velasco-Rodríguez, Aránzazu García-Raso and Gala Vega collected the data; Juan-Manuel Alonso-Domínguez and Aránzazu García-Raso analyzed the data; Diego Velasco-Rodríguez wrote the paper; Juan-Manuel Alonso-Domínguez, Carlos Blas, Carlos Soto, Gala Vega, Aránzazu García-Raso and Pilar LlamasSillero reviewed the paper.

Conflicts of Interest: The authors declare no conflict of interest.

\section{References}

1. Harteveld, C.L.; Higgs, D.R. Alpha-thalassaemia. Orphanet J. Rare Dis. 2010, 5, 13. [CrossRef] [PubMed]

2. Lau, Y.L.; Chan, L.C.; Chan, Y.Y.; Ha, S.Y.; Yeung, C.Y.; Waye, J.S.; Chui, D.H. Prevalence and genotypes of alpha- and beta-thalassemia carriers in Hong Kong-Implications for population screening. N. Engl. J. Med. 1997, 336, 1298-1301. [CrossRef] [PubMed]

3. Li, Z.; Li, F.; Li, M.; Guo, R.; Zhang, W. The prevalence and spectrum of thalassemia in Shenzhen, Guangdong Province, People's Republic of China. Hemoglobin 2006, 30, 9-14. [CrossRef] [PubMed]

4. Vichinsky, E.P. Alpha thalassemia major-New mutations, intrauterine management, and outcomes. Hematol. Am. Soc. Hematol. Educ. Program 2009, 35-41. [CrossRef] [PubMed]

5. Michlitsch, J.; Azimi, M.; Hoppe, C.; Walters, M.C.; Lubin, B.; Lorey, F.; Vichinsky, E. Newborn screening for hemoglobinopathies in California. Pediatr. Blood Cancer 2009, 52, 486-490. [CrossRef] [PubMed]

6. Lal, A.; Goldrich, M.L.; Haines, D.A.; Azimi, M.; Singer, S.T.; Vichinsky, E.P. Heterogeneity of hemoglobin H disease in childhood. N. Engl. J. Med. 2011, 364, 710-718. [CrossRef] [PubMed]

7. Vichinsky, E. Advances in the treatment of alpha-thalassemia. Blood Rev. 2012, 26 (Suppl. S1), S31-S34. [CrossRef]

8. Weatherall, D.J.; Clegg, J.B. Inherited haemoglobin disorders: An increasing global health problem. Bull. World Health Organ. 2001, 79, 704-712. [PubMed]

9. Williams, T.N.; Weatherall, D.J. World distribution, population genetics, and health burden of the hemoglobinopathies. Cold Spring Harb. Perspect. Med. 2012, 2, A011692. [CrossRef] [PubMed]

10. Higgs, D.R.; Vickers, M.A.; Wilkie, A.O.; Pretorius, I.M.; Jarman, A.P.; Weatherall, D.J. A review of the molecular genetics of the human $\alpha$-globin gene cluster. Blood 1989, 73, 1081-1104. [PubMed]

11. Higgs, D.R. The molecular basis of $\alpha$-thalassemia. Cold Spring Harb. Perspect. Med. 2013, 3, A011718. [CrossRef] [PubMed]

12. Vichinsky, E.P. Clinical manifestations of $\alpha$-thalassemia. Cold Spring Harb. Perspect. Med. 2013, 3, A011742. [CrossRef] [PubMed] 
13. Villegas, A.; Porres, A.; Sánchez, J.; González, F.A.; Pérez-Clausell, C.; Martínez, M.; Murga, M.J.; Cachá, J.; Lozano, M.; Fernández-Fuertes, I.; et al. Red blood cell phenotypes in alpha-thalassemias in the Spanish population. Haematologica 1998, 83, 99-103. [PubMed]

14. Akhavan-Niaki, H.; Kamangari, R.Y.; Banihashemi, A.; Oskooei, V.K.; Azizi, M.; Tamaddoni, A.; Sedaghat, S.; Vakili, M.; Nesheli, H.M.; Shabani, S. Hematologic Features of Alpha Thalassemia Carriers. Int. J. Mol. Cell. Med. 2012, 1, 162-167. [PubMed]

15. Ataulfo González, F.; Blázquez, C.; Ropero, P.; Briceño, O.; Alaez, C.; Polo, M.; Benavente, C.; Mateo, M.; Peña, A.; Villegas, A. Association of hemoglobinopathy and alpha thalassemia. Study of 45 patients. Med. Clin. 2005, 124, 726-729.

16. Wambua, S.; Mwacharo, J.; Uyoga, S.; Macharia, A.; Williams, T.N. Co-inheritance of alpha+-thalassaemia and sickle trait results in specific effects on haematological parameters. Br. J. Haematol. 2006, 133, $206-209$. [CrossRef] [PubMed]

17. Gringras, P.; Wonke, B.; Old, J.; Fitches, A.; Valler, D.; Kuan, A.M.; Hoffbrand, V. Effect of alpha thalassaemia trait and enhanced gamma chain production on disease severity in beta thalassaemia major and intermedia. Arch. Dis. Child. 1994, 70, 30-34. [CrossRef] [PubMed]

18. Fucharoen, S.; Viprakasit, V. Hb H disease: Clinical course and disease modifiers. Hematol. Am. Soc. Hematol. Educ. Program 2009, 26-34. [CrossRef] [PubMed]

19. Harteveld, C.L.; Voskamp, A.; Phylipsen, M.; Akkermans, N.; den Dunnen, J.T.; White, S.J.; Giordano, P.C. Nine unknown rearrangements in 16p13.3 and 11p15.4 causing $\alpha$ - and $\beta$-thalassaemia characterised by high resolution multiplex ligation-dependent probe amplification. J. Med. Genet. 2005, 42, 922-931. [CrossRef] [PubMed]

20. Ahmad, R.; Saleem, M.; Aloysious, N.S.; Yelumalai, P.; Mohamed, N.; Hassan, S. Distribution of alpha thalassaemia gene variants in diverse ethnic populations in Malaysia: Data from the institute for medical research. Int. J. Mol. Sci. 2013, 14, 18599-18614. [CrossRef] [PubMed]

21. Villegas, A.; Ropero, P.; González, F.A.; Anguita, E.; Espinós, D. The thalassemia syndromes: Molecular characterization in the Spanish population. Hemoglobin 2001, 25, 273-283. [CrossRef] [PubMed]

22. Villegas, A.; Sánchez, J.; Sal del Río, E. Alpha globin genotypes in a Spanish population. Hemoglobin 1992, 16, 427-429. [CrossRef] [PubMed]

23. Ryan, K.; Bain, B.J.; Worthington, D.; James, J.; Plews, D.; Mason, A.; Roper, D.; Rees, D.C.; De La Salle, B.; Streetly, A. British Committee for Standards in Haematology. Significant haemoglobinopathies: Guidelines for screening and diagnosis. Br. J. Haematol. 2010, 149, 35-49. [CrossRef] [PubMed]

24. Brugnara, C.; Mohandas, N. Red cell indices in classification and treatment of anemias: From M.M. Wintrobe's original 1934 classification to the third millennium. Curr. Opin. Hematol. 2013, 20, 222-230. [CrossRef] [PubMed]

25. Dallman, P.R.; Siimes, M.A. Percentile curves for hemoglobin and red cell volume in infancy and childhood. J. Pediatr. 1979, 94, 26-31. [CrossRef]

26. Aldrimer, M.; Ridefelt, P.; Rödöö, P.; Niklasson, F.; Gustafsson, J.; Hellberg, D. Population-based pediatric reference intervals for hematology, iron and transferrin. Scand. J. Clin. Lab. Investig. 2013, 73, 253-261. [CrossRef] [PubMed]

27. Williams, T.N.; Maitland, K.; Ganczakowski, M.; Peto, T.E.A.; Clegg, J.B.; Weatherall, D.J.; Bowden, D.K. Red blood cell phenotypes in the alpha+ thalassaemias from early childhood to maturity. Br. J. Haematol. 1996, 95, 266-272. [CrossRef] [PubMed]

28. Chong, S.S.; Boehm, C.D.; Higgs, D.R.; Cutting, G.R. Single-tube multiplex-PCR screen for common deletional determinants of alpha-thalassemia. Blood 2000, 95, 360-362. [PubMed]

(C) 2017 by the authors. Licensee MDPI, Basel, Switzerland. This article is an open access article distributed under the terms and conditions of the Creative Commons Attribution (CC BY) license (http:// creativecommons.org/licenses/by/4.0/). 